\title{
Composite Concrete Modifier CM 02-10 and Its Impact on the Strength Characteristics of Concrete
}

\author{
Luka Akimov ${ }^{1, a}$, Nikita llenko ${ }^{1}$, Roman Mizharev ${ }^{1}$, Artemiy Cherkashin ${ }^{1}$, Nikolay Vatin $^{1}$ and Ludmila \\ Chumadova $^{1}$ \\ ${ }^{1}$ Peter the Great Saint-Petersburg Polytechnic University, 29 Polytechnicheskaya st., St.Petersburg, 195251, \\ Russian Federation
}

\begin{abstract}
The main aim of this research is the investigation of effect of the composite additive (a mixture of hyperplasticizer and microsilica) CM 02-10 (10\% of MS and 0.2\% of HP) on strength characteristics of concrete. Interaction of concrete with plasticizing and siliceous additives individually depending on their percentage content by the weight of cement is also investigated. Results of experiments with such additives on the fluidity of concrete mix and strength of concrete are presented. Additives used in the experiment: superplasticizer S-3, fused microsilica FMS-85, hyperplasticizer PENTAFLOW AC 2, and composite additive CM 02-10. In this paper results of tests of samples aged 3, 7 and 28 days are presented.
\end{abstract}

\section{Introduction}

The feature of life nowadays is an erection of different high-rise and unique buildings and constructions [1]. According to this, materials, concrete in particular, have to solve many problems which arise in the process of building. Filler materials-modifiers were aimed to help in solving these problems.

An advisability of using filler materials-modifiers comes from technical requirements and economic gain, which includes qualitative characteristics of materials adding to concrete or mortar, in condition of saving expensive concrete.

A decrease of using cement is the government support of Russian Federation "Energy conservation and energy efficiency for the period up to 2020".

The main goal of this research is to compare known plasticizing and siliceous additives with the new combined additive CM 02-10 in their impact on the concrete properties. It is extremely important to determine which of these additives could provide the highest mobility and strength to a concrete mix.

It is expected that the new additive will be applied at all stages of construction, where high workability and strength of concrete are necessary.

To achieve these goals series of experiments with modified concrete samples were held.

\footnotetext{
${ }^{\mathrm{a}}$ Corresponding author: lukas-ak@mail.ru
} 


\section{A brief characteristics of additives-components of the composite additive and an overview of previous researches}

\subsection{Hyper and superplasticizer}

Plasticizing additives are used to increase a mobility of concrete. These additives were called dewatering (water reducing) additives because of their ability to reduce mixing rate. By using these additives, it becomes possible to reduce water-cement ratio to 40-45\% while maintaining the necessary mobility [2-6]. These materials are classified as surfactant-active substances (surfactants) [7]. One of the most popular plasticizer additive is superplasticizer S-3.

Superplasticizer S-3 is a reliable water reducing additive, which has been used for a long time. S-3 is used in all types of concreting: monolithic and precast. S-3 is a mixture of sodium salts poly-metilmethylene-naphthalenes-sulfonic of various molecular weights $[8,9]$.

According to the data given in [4], applying S-3 allows to get the following indicators:

- increase of mobility of the concrete mix from P1 to P2;

- reduce of water demand during mixing with the binder by $20-25 \%$;

- increase of final strength characteristics by $25 \%$ and more.

With the introduction of this additive the heat generation also reduces in the early period up to 20 $\%[10]$.

Hyperplasticizer HP, which is made on the basis of polycarboxylate ethers, is another example of plasticizers. HP has larger water reducing properties than superplasticizer, therefore it is could be used in a smaller amount $[11,12]$. This additive is used to provide the maximum possible strength of the concrete by reducing water-cement ratio.

In [5] is described how the effect of plasticizers influences on the physical and mechanical properties of normal weight concrete hardening at the age of 1, 3, 7 and 28 days. The main conclusion of the research:

- the introduction of the investigated additives in a concrete mixture enables a significant increase in density, strength, water resistance and frost resistance of concrete

\subsection{Siliceous mineral additive}

Amorphous microsilica may be treated as the most effective mineral modifier and, therefore, it is used as the most popular additive in a concrete. It makes cement stone more durable and long-lasting [1315]. Microsilica is a product of oxidation of gaseous silicon generated during high temperature manufacturing.

Microsilica is an ultrafine material which is produced from spherical particles which are byproducts in the process of gas purification furnaces in the production of silicon-containing alloys, that is confirmed by the specification 5743-048-02495332-96. The permissible content of an amorphous modification of silicon dioxide which is the main component of microsilica should be not higher than $30 \%$ by the weight of cement.

Microsilica differs from other additives by the small size of particles (100 to $500 \mathrm{~nm})$ and the high specific surface [15-17].

Pozzolanic MS activity and high dispersion of particles cause positive impact of MS on structure, physical and mechanical properties of concrete.

The silica reacts with the calcium hydroxide formed during hydration of silicate phases of cement to form low-basic calcium hydrosilicates. High specific surface area of microsilica (13000-25000 $\mathrm{m}^{2} /$ $\mathrm{kg}$ ) intensifies the formation of the products of hydration, therefore, the sharing of microsilica in an amount of $5 \%$ by the weight of cement with plasticizer should increase the strength of fine concrete $[18,19]$.

According to the experimental data [20], consumption of cement in the control part of sand concrete was $500 \mathrm{~kg}$ per $1 \mathrm{~m}^{3}$ of mix. Cement mark is M500 with normal consistency $25 \%$. Fillers, 
that were introduced into the sand concrete, have replaced fixed amount of cement in the mixture; the dosage of superplasticizer was $0.5 \%$ by the weight of cement. Fluidity of cement paste was a constant in all formulations. The combined use of crushed quartz sand in an amount of $5 \%$ by the weight of cement with a plasticizer S-3 cause a significant increase in the strength of fine concrete [21].

\subsection{Composite concrete modifier CM 10-01}

Concrete modifier, which is described in [22], is able to increase the strength of concrete in 2-2.5 times. This modifier is called CM-01, it was engaged in the development of modifier Kaprielov S. S. Concrete modifier $\mathrm{CM}-01$ is an organo-mineral-based powdered product, containing a fused microsilica and superplasticizer S-3. Series 10-01 CM of such modifiers are the most widely used in modification of concrete mixture. It consists of $90 \%$ of amorphous microsilica and $10 \%$ of superplasticizer-3. Under normal conditions Portland cement hydration results to forming up to $40 \%$ of portlandite in the structure of the cement paste-crystalline calcium hydroxide.

Portlandite includes large crystals, which are comparably easy-soluble in water $\left(1.65 \mathrm{~g} / 1\right.$ at $20^{\circ}$ C) and have low strength and hardness ( 2 in accordance with Mohs' scale). Portlandite forms mostly when a concrete streams. There is a variety of amorphous silicon dioxide, which can react with calcium hydroxide in pozzolanic reaction at ordinary temperatures:

$$
\mathrm{Ca}(\mathrm{OH})_{2}+\mathrm{SiO}_{2}+(n-1) \mathrm{H}_{2} \mathrm{O}=\mathrm{CaOSiO}_{2} \cdot n \mathrm{H}_{2} \mathrm{O}=\mathrm{CaOSiO}{ }_{2} \cdot n \mathrm{H}_{2} \mathrm{O}
$$

This kind of amorphous silica is called amorphous (or active) silica or pozzolan. In accordance with [20], it is possible to improve the strength of cement stone by reducing the amount of portlandite in the total mass of growth, it happens because this mineral is the weakest in comparison with others and also degrades the contact zone between the aggregates and the cement. One of the ways to reduce the portlandite in the system is to use active mineral components, namely microsilica brand FMS- 85 .

Basing on the experience of previous researches, using the standard documentation and own experimental data, we can develop an additive that will be used in the composition of concrete or grout, as well as pick up raw materials from which additives will be produced. By analyzing the effect of additives the efficiency of improving the strength and plasticizing properties becomes clear. Data requirements are met by the addition of $\mathrm{CM}-01$, described in [22], which has no difficulty in obtaining, in view of the prevalence of plasticizer S-3 and the wide availability of microsilica.

\section{Materials and Methods}

Basing on the [20-22], a modifying composition similar to a CM 10-01 [20] is proposed in this research. It is composed of $98 \%$ of microsilica MS-85 and $2 \%$ of hyperplasticizer Pentaflow AC2. It is used in conjunction with a cement at a weight fraction of $0.2 \%$ of hyperplasticizer and of $10 \%$ of microsilica by the weight of a cement. Saving a plasticizer for almost similar values of strength with increasing content of the HP in relation to the cement is the rationale for minimum dosage of HP, which is used in the range from 0.2 to $0.6 \%$ by the weight of cement. The amount of MS- 85 in this composition is the same as in the CM 10-01 for the subsequent comparison of the strength results of researches $[20,23]$, in which $10 \%$ of silica is also used.

In the course of the experiments materials described in Table. 1 were used. 
Table 1. Materials used in the course of experiments.

\begin{tabular}{|c|c|}
\hline Material & Specification \\
\hline Cement & $\begin{array}{c}\text { Portland cement of Sukholozhskoye's cement plant } \\
\text { with strength class 42.5 normally- hardening CEM I } \\
42.5 \text { H GOST 31108-2003 }\end{array}$ \\
\hline Sand & I class sand with middle size of particles (depending \\
& on GOST 8736-93) \\
\hline Water & depending on GOST 23732-2011 \\
\hline Rubble & depending on GOST 8736-93 \\
\hline Plasticizing & $\begin{array}{c}\text { Superplasticizer S-3 (specification 5870-34-00369171- } \\
\text { 02) and Hyperplasticizer PENTAFLOW AC 2 }\end{array}$ \\
\hline $\begin{array}{c}\text { Siliceous } \\
\text { additive }\end{array}$ & $\begin{array}{c}\text { Fused microsilica FMS-85 (specification 5743-048- } \\
\text { 02495332-96) }\end{array}$ \\
\hline
\end{tabular}

On the first step of determination of the efficiency on the strength characteristics of the additive in concrete 5 kinds of cement mortars with different additives were prepared, in accordance with GOST 30459-2008. One of the mortars was controlling which was prepared without additives for subsequent tests at the age of 3, 7, 28 days. We were using forms depending on GOST 22685-89 7 to prepare samples of a prism form (bar, which is the equivalent of cube) with dimensions $50 \times 50 \times 150 \mathrm{~mm}$. The controlling composition - composition No.1 without additives. Composition and consumption of materials with witch the bars were prepared are shown in Table. 2.

Table 2. Consumption of materials for the prism bars of cement mortar.

\begin{tabular}{|c|c|c|c|c|c|}
\hline No. & $\begin{array}{c}\text { Sand, } \\
\left(\mathrm{kg} / \mathrm{m}^{3}\right)\end{array}$ & $\begin{array}{c}\text { Cement, } \\
\left(\mathrm{kg} / \mathrm{m}^{3}\right)\end{array}$ & $\begin{array}{c}\text { Additive and its percentage by } \\
\text { the weight of cement }\end{array}$ & W/C & $\begin{array}{c}\text { Flow of } \\
\text { cone, }(\mathrm{mm})\end{array}$ \\
\hline 1 & 1500 & 500 & - & 0.50 & 110 \\
\hline 2 & 1500 & 500 & $\mathrm{HP}(0.2 \% \mathrm{C})$ & 0.40 & 107 \\
\hline 3 & 1500 & 500 & $\mathrm{~S}-3(0.7 \% \mathrm{C})$ & 0.45 & 108 \\
\hline 4 & 1500 & 500 & $\mathrm{MS}(10 \% \mathrm{C})$ & 0.51 & 107 \\
\hline 5 & 1500 & 500 & $\mathrm{CM} 02-10(10.2 \% \mathrm{C})$ & 0.43 & 110 \\
\hline
\end{tabular}

With the same flow of cone $( \pm 3 \mathrm{~mm})$ different strength is expected due to the difference in watercement ratio. The bars of cement and sand were stored and tested under normal conditions in water in accordance with GOST 5802-86.

Calorimetric studies of the kinetics of hydration of cement [24-27] allow us to assess the activity of additives. On the basis of previous calorimetric studies of the kinetics of hydration of cement with additives and on the basis of studies of the strength of cement bars, in accordance with GOST 2700686 two compositions of heavy concrete were developed. The first was a controlling, CM 02-10 was added in the second. Composition of concrete mixtures provided the same mobility (FoC). Amount of additive CM 02-10 is the same as in the case of cement-sand samples $-10.2 \%$ by the weight of cement.

For the experiment some samples were prepared (concrete cubes with the size of the ribs $100 \mathrm{~mm}$ ) in accordance with GOST 10180-2012 for determining the strength at 3, 7, 28 days of 2 different compositions. Composition №1 is controlling (Table. 3).

Table 3. The composition of the concrete cubes.

\begin{tabular}{|c|c|c|c|c|c|c|c|c|c|}
\hline \multicolumn{6}{|c|}{ The composition of the concrete mix, $\left[\mathrm{kg} / \mathrm{m}^{3}\right]$} & \multirow[b]{2}{*}{$\mathrm{W} / \mathrm{C}$} & \multirow{2}{*}{$\begin{array}{c}\text { Flow } \\
\text { of } \\
\text { Cone, } \\
(\mathrm{cm})\end{array}$} & \multirow{2}{*}{$\begin{array}{l}\text { Mark of the } \\
\text { workability }\end{array}$} & \multirow{2}{*}{$\begin{array}{c}\text { Density } \\
\text { of the } \\
\text { mixture, } \\
\left(\mathrm{kg} / \mathrm{m}^{3}\right)\end{array}$} \\
\hline No & cement & $\begin{array}{c}\text { CM 02- } \\
10\end{array}$ & sand & rubble & water & & & & \\
\hline 1 & 550 & - & 595 & 870 & 242 & 0.44 & 19 & W4 & 2257 \\
\hline 2 & 550 & 56.1 & 650 & 950 & 215 & 0.39 & 21 & W5 & 2421 \\
\hline
\end{tabular}


Concrete cubes were stored in normal conditions of temperature $(20 \pm 2){ }^{\circ} \mathrm{C}$ and relative humidity of $(95 \pm 5) \%$.

Next, the test of concrete samples was held by destructive method in a hydraulic press. The test results of concrete samples under compression are shown in Table. 5 and in Fig. 2.

\section{Results and Discussion}

Compression-force test was held on 50-ton press. According to test results on the compressive strength of bars (Table 4), the graphs of strength changes over time were constructed (Fig. 1).

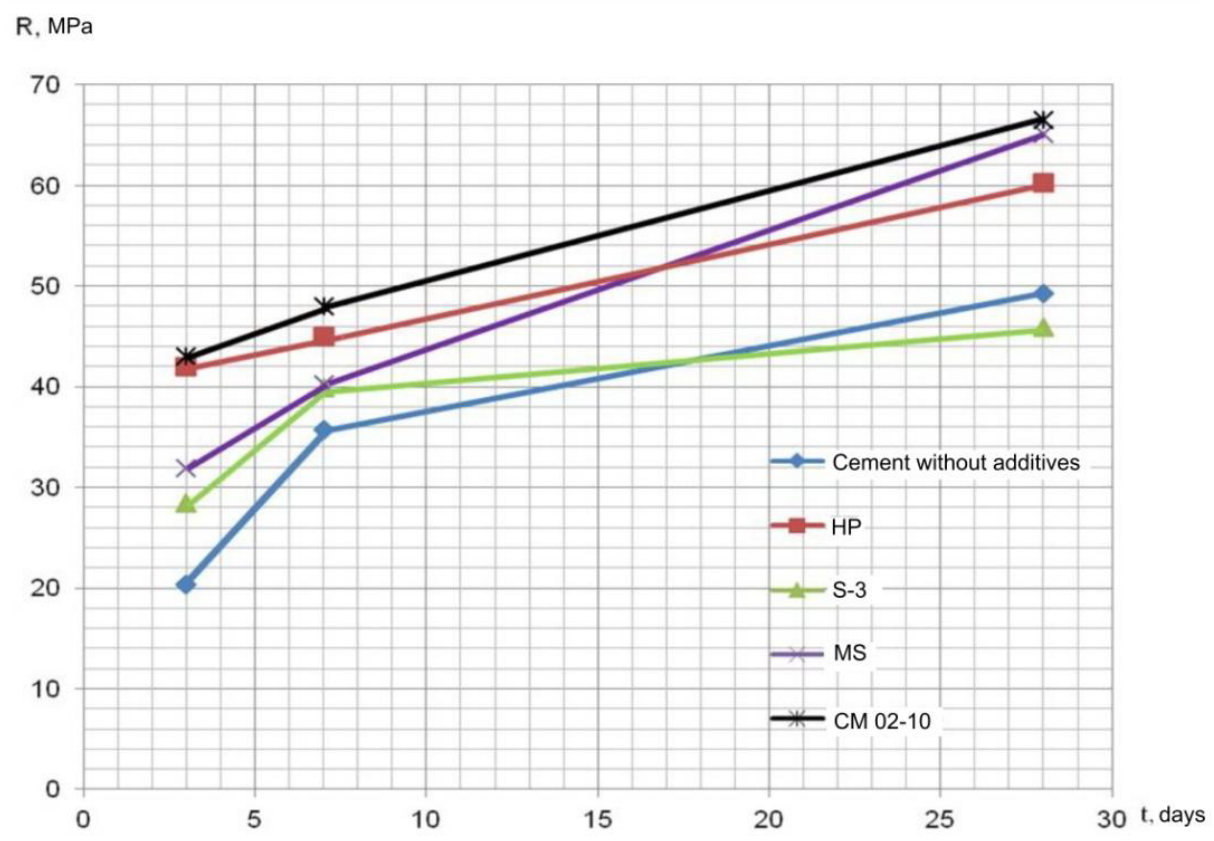

Figure 1. Strength variation (R) of samples over time at 3, 7, 28 days.

Table 4. The results of the strength test of the bars.

\begin{tabular}{|c|c|c|c|c|c|c|c|c|c|}
\hline \multirow{3}{*}{ No. } & \multirow{3}{*}{ Additive } & \multirow{3}{*}{$\mathrm{W} / \mathrm{C}$} & \multirow{3}{*}{$\begin{array}{l}\text { FoC, } \\
(\mathrm{mm})\end{array}$} & \multicolumn{6}{|c|}{ Strength of the bars, (MPa) } \\
\hline & & & & \multicolumn{2}{|c|}{3 days } & \multicolumn{2}{|c|}{7 days } & \multicolumn{2}{|c|}{28 days } \\
\hline & & & & $\mathrm{R}_{\text {bend }}$ & $\mathrm{R}_{\text {comn }}$ & $\mathrm{R}_{\text {bend }}$ & $\mathrm{R}_{\text {comp }}$ & $\mathrm{R}_{\text {bend }}$ & $\mathrm{R}_{\text {comn }}$ \\
\hline 1 & - & 0.50 & 110 & 5.4 & $\frac{20.4 *}{100 \%}$ & 8.5 & $\frac{35.7^{*}}{100 \%}$ & 7.8 & $\frac{49.2^{*}}{100 \%}$ \\
\hline 2 & $\mathrm{HP}$ & 0.40 & 107 & 8.8 & $\frac{42 *}{206 \%}$ & 6.7 & $\frac{45^{*}}{126 \%}$ & 7.5 & $\frac{60.2 *}{122 \%}$ \\
\hline 3 & S-3 & 0.45 & 108 & 8.2 & $\frac{28.4 *}{139 \%}$ & 5.7 & $\frac{39.9 *}{112 \%}$ & 6.2 & $\frac{45.9^{*}}{93 \%}$ \\
\hline 4 & MS & 0.51 & 107 & 5.5 & $\frac{32 *}{157 \%}$ & 6.5 & $\frac{40.3^{*}}{113 \%}$ & 8.3 & $\frac{65.1 *}{132 \%}$ \\
\hline 5 & $\begin{array}{c}\text { CM02- } \\
10\end{array}$ & 0.43 & 110 & 6.7 & $2 \frac{43 *}{211 \%}$ & 7.8 & $\frac{48^{*}}{134 \%}$ & 8 & $\frac{66.5^{*}}{135 \%}$ \\
\hline
\end{tabular}

*Note: above the line - the average value of the index; below the line - the relative value of the index in $\%$ of controlling composition.

According to the received information, there is a significant increase of strength of cement with CM 02-10 to the third day unlike cement without additives. 
On the 7th day of hardening the cement strength of bars with the MS and S-3 is almost the same (1 $\%$ difference). The value of strength of the bars with HP is $13 \%$ more than the bars with MS, which polar changes to the 28th day, when strength value of the bars with MS is $10 \%$ more than the bars with HP. Studying strength of samples with S-3 leads to the conclusion that as the amount of unhydrated cement decreases the SAS membrane becomes thicker, thus, the hardening speed decreases.

Strength curve for the bars with S-3 shows the worst results, so in the future it will not be discussed.

Thus, the combination of $10 \%$ of MS and $0.2 \%$ of HP (CM 02-10) in the cement solution gives a strength by $35 \%$ higher in comparison with a cement without additives.

With the addition of CM 02-10 the strength of cement bars, compared to other prototypes of the same cement content with the same mobility, increases, it serves as a basis for the development of heavy concrete with the use of this additive.

Table 5. The results of compression test of the concrete cubes.

\begin{tabular}{|c|c|c|c|c|c|c|c|c|c|}
\hline \multirow[b]{2}{*}{ No. } & \multirow[b]{2}{*}{$\begin{array}{l}\text { CM 02- } \\
10, \\
\left(\mathrm{~kg} / \mathrm{m}^{3}\right)\end{array}$} & \multirow{2}{*}{$\begin{array}{l}\text { Amount } \\
\text { of } \\
\text { cement } \\
\text { in } \\
\text { concrete, } \\
\left(\mathrm{kg} / \mathrm{m}^{3}\right)\end{array}$} & \multirow[b]{2}{*}{$\mathrm{W} / \mathrm{C}$} & \multirow[b]{2}{*}{$\begin{array}{l}\text { Density } \\
\text { of mix, } \\
\left(\mathrm{kg} / \mathrm{m}^{3}\right)\end{array}$} & \multicolumn{3}{|c|}{$\begin{array}{l}\text { Compressive strength } \mathrm{R}, \\
{[\mathrm{MPa}]}\end{array}$} & \multirow[b]{2}{*}{$\begin{array}{l}\text { Class of } \\
\text { concrete }\end{array}$} & \multirow{2}{*}{$\begin{array}{l}\text { Specific } \\
\text { consumptio } \\
\mathrm{n} \text { of binder } \\
\text { per unit of } \\
\text { designed } \\
\text { strength, } \\
(\mathrm{kg} / \mathrm{MPa})\end{array}$} \\
\hline & & & & & 3 days & 7 days & $\begin{array}{l}28 \\
\text { days }\end{array}$ & & \\
\hline 1 & - & 550 & 0.44 & 2257 & 28.2 & 37.6 & 44 & C35 & 12.5 \\
\hline 2 & 56.1 & 550 & 0.39 & 2421 & 35.3 & 38.9 & 56.4 & C45 & 9.75 \\
\hline
\end{tabular}

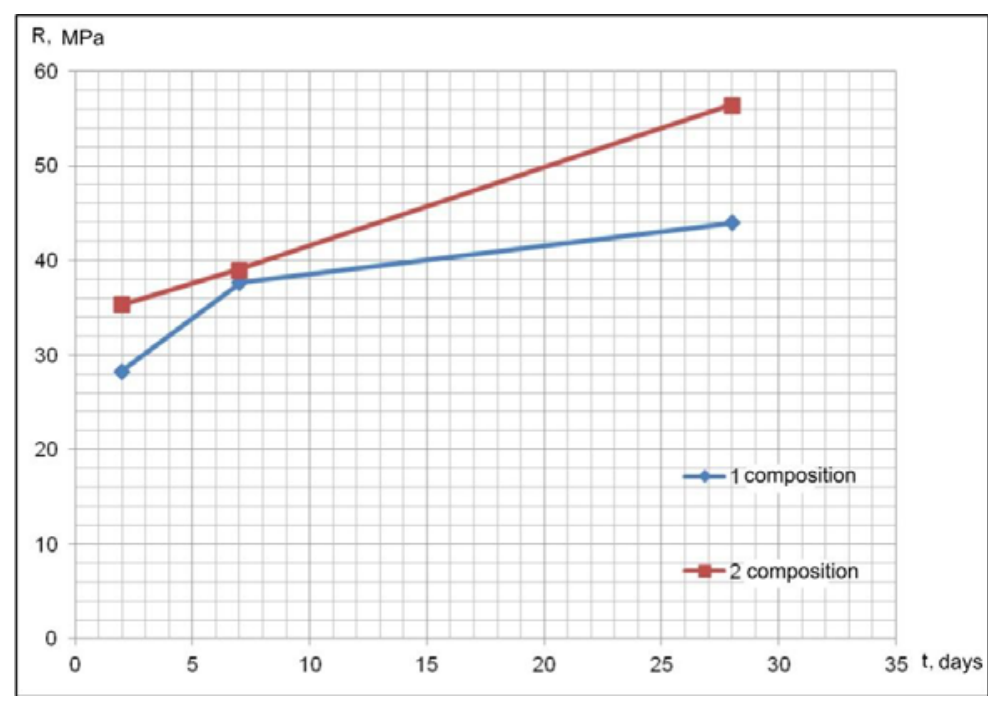

Figure 2. Change in strength values of the concrete cubes over time.

As we can see in the results of experiment (Fig. 2), the samples of the concrete, modified by CM 02-10, have a stable increasing in the strength. This fact allows us to predict more gains of it over time. Compressive strength of concrete sample No.2 is $128 \%$ higher than the strength of the control sample in the age of 28 days. It illustrates the effectiveness of using an additive CM 02-10 when its content is $10.2 \%$ by the weight of cement with the same cement consumption. 


\section{Conclusions}

After analyzing the effect of various additives on the concrete strength characteristics, it is possible to find out the following conclusions:

1. By adding CM 02-10 to a concrete mix we could conclude, that this additive has the most positive influence on the strength characteristics of the cement beams. At the age of 28 days we could observe the increasing of strength compare to a controlling sample:

- $122 \%$ using HP;

- $132 \%$ using MS;

- $135 \%$ using CM 02-10.

2. Cement mortar have similar rates of mobility comparing to cement mortar without any additives by reducing $\mathrm{W} / \mathrm{C}$ :

- $20 \%$ using HP;

- $10 \%$ using S-3;

- $14 \%$ using CM 02-10.

It is possible to conclude considering the results of experiments (Fig. 1 and Fig. 2) that the concrete prepared with the mixture of hyperplasticizer and microsilica shows the best strength values, thereby, using of an additive CM 02-10 as a modified additive to concrete is reasonable.

\section{References}

1. EN 1992 Eurocode 2. Design of concrete structures.

2. I.N. Akhverdov, Osnovy fiziki betona (M., Stroyizdat, il. UDK 666.972.017:53, 1981)

3. A.V. Usherov-Marshak, M. Tsiak, Khimicheskiye i mineralnyye dobavki v tekhnologii tsementa $i$ betona (Zaporozhye: Khortitsa, 2002)

4. Company "Polylayer", Pop. conc., 2, 70-74 (2004)

5. V.S. Izotov, R.A. Ibragimov, Izvest. KGASU, Kazan, 1 (13), 287-291 (2010)

6. Electronic directory of a builder [web source] (20.12.2013). URL: http://www.bibliotekar.ru/spravochnik-70/26 (date of reference: 18.09.2015)

7. P.G. Vasilik, I.V. Golubev, Publication of electronic resource of company ZAO "EuroChem- 1". Features of the application of polycarboxylate hyperplasticizer Melfluxâ [web source] (16.02.2014). URL: http://www.chem.eurohim.ru/catalog/DryMortarAdditives/articles/art52 (date of reference: 15.09 .2015$)$

8. Yu.G. Barabanshchikov, M.V. Komarinskiy, Adv. Mat. Res., 941 (944), 780-785 (2014)

9. S.S. Kiski, I.V. Ageyev, A.N. Ponomarev, A.A. Kozeyev, M.E. Yudovich, Civil Eng. J., 8, 42-46 (2012)

10. Ta Van Fan, Samouplotnyayushchiyesya vysokoprochnyye betony s zoloy risovoy shelukhi $i$ metakaolinom (Abstract Ph.D., Rostov-na-Donu, 2013)

11. N.P. Bleshchik, N.N. Kalinovskaya, Modern concrete (IX international scientific conference, Zaporozhye, 2007)

12. N.P. Bleshchik, N.N. Kalinovskaya, Constr. Sc. and Tech., 1, 30-40 (2006)

13. V.I. Kalashnikov, O.V. Tarakanov, Yu.S. Kuznetsov, V.M. Volodin, Ye.A. Belyakova, Civil Eng. J., 8, 47-52 (2012)

14. X. Zhang, S. Yang, B. Diao, Q. Zhang, Y. Li, J. of Build. Str., 30 (2), 324-327 (2009)

15. A. Sprince, G. Fischer, L. Pakrastinsh, A. Korjakins, Adv. Mat. Res., 842, 470-476 (2012)

16. U.G. Distanov, Mineralnoye syrye. Opal-kristobalitovyye porody: spravochnik (M. ZAO "Geoinformmark", 1998)

17. G.V. Nesvetayev, G.S. Kardumyan, Ta Van Fan, L.A. Khomich, A.M. Blyagoz, Nov. tekh., 4, 125-128 (2012)

18. G.V. Nesvetayev, G.S. Kardumyan, Ta Van Fan, L.A. Khomich, A.M. Blyagoz, Nov. tekh., 4, $122-125$ (2012) 
19. G.V. Nesvetayev, G.S. Kardumyan, Ta Van Fan, L.A. Khomich, A.M. Blyagoz, Nov. tekh., 4, 118-121 (2012)

20. N.M. Morozov, Kh.G. Muginov, V.G. Khozin, A.B. Antakov, Izvest. KGASU, Kazan, 2 (20), $183-188$ (2012)

21. L.A. Veshnyakova, A.M. Ayzenshtadt, Proc. IV Int. Sem.-cont. of young sc. and grad. stud. work. in the f. of bind., conc. and dry m., 5, 164 (2013)

22. Publication of the electronic version of the journal "StroyPROFIl" [web source] (05.06.2007). URL: http://stroyprofile.com/archive/2652 (date of reference: 20.09.2015)

23. Ye.G. Matveyeva, Povysheniye effektivnosti betona dobavkoy nanodispersnogo kremnezema, (Abstract Ph.D., Belgorod, 2011)

24. Yu.G. Barabanshchikov, A.V. Churillo, Heat dissipation binders. Methodical instructions, (A.: LPI, St.Petersburg, 1988)

25. L.I. Chumadova, et al., Posobiye po teplovoy obrabotke sbornykh zhelezobetonnykh konstruktsiy $i$ izdeliy.(podgotovka k SNiP 3.09.01-89), (M. Stroyizdat., St. Petersburg, 1989)

26. I.D. Zaporozhets, A.A. Pariyskiy, S.D. Okorokov, L.I. Chumadova, Concrete and Reinforced Concrete, 6, 52-62 (1977)

27. A.S. Vasilyev, Yu.G. Barabanshchikov, Civil Eng. J., 8, 67-77 (2012) 